\title{
Genome-wide gene expression pattern underlying differential host response to high or low pathogenic H5N1 avian influenza virus in ducks
}

\author{
A. KUMAR ${ }^{1 \#}$, P. VIJAYAKUMAR ${ }^{1 \#}$, P. N. GANDHALE ${ }^{1}$, P. B. RANAWARE ${ }^{1}$, H. KUMAR ${ }^{2}$, D. D. KULKARNI ${ }^{1}$, \\ A. A. RAUT ${ }^{1}$, A. MISHRA ${ }^{1 *}$
}
${ }^{1}$ ICAR- National Institute of High Security Animal Diseases, Anand Nagar, Bhopal-462021, Madhya Pradesh, India; ${ }^{2}$ Laboratory of Immunology, Department of Biological Sciences, Indian Institute of Science Education and Research, Bhopal-462066, Madhya Pradesh, India

Received May 13, 2016; revised August 8, 2016; accepted January 30, 2017

\begin{abstract}
Summary. - The differences in the influenza viral pathogenesis observed between different pathogenic strains are associated with distinct properties of virus strains and the host immune responses. In order to determine the differences in the duck immune response against two different pathogenic strains, we studied genome-wide host immune gene response of ducks infected with A/duck/India/02CA10/2011 and A/duck/ Tripura/103597/2008 H5N1 viruses using custom-designed microarray. A/duck/India/02CA10/2011 is highly pathogenic virus (HP) to ducks, whereas A/duck/Tripura/103597/2008 is a low pathogenic (LP) virus strain. Comparative lung tissue transcriptome analysis of differentially expressed genes revealed that 686 genes were commonly expressed, 880 and 1556 genes are expressed uniquely to infection with HP and LP virus, respectively. The up-regulation of chemokines (CCL4 and CXCR4) and IFN-stimulated genes (IFITM2, STAT3, TGFB1 and TGFB3) was observed in the lung tissues of ducks infected with HP virus. The up-regulation of other immune genes (IL17, OAS, SOCS3, MHC I and MHC II) was observed in both infection conditions. The expression of important antiviral immune genes MX, IFIT5, IFITM5, ISG12, $\beta$-defensins, RSAD2, EIF2AK2, TRIM23 and SLC16A3 was observed in LP virus infection, but not in HP virus infection. Several immune-related gene ontology terms and pathways activated by both the viruses were qualitatively similar but quantitatively different. Based on these findings, the differences in the host immune response might explain a part of the difference observed in the viral pathogenesis of high and low pathogenic influenza strains in ducks.
\end{abstract}

Keywords: ducks; avian influenza virus infection; differential host immune response; microarray

\section{Introduction}

Influenza A viruses are divided into different subtypes on the basis of the surface viral glycoproteins hemagglutinin (HA) and neuraminidase (NA). Currently, 18 known HA and 11 known NA subtypes were reported (CDC, 2015). Of these,

\footnotetext{
"Corresponding author: E-mail: reach2anamika@yahoo.com; phone: +919229131508 (mobile). ${ }^{*}$ Authors contributed equally to this work.

Abbreviations: $\mathrm{AI}(\mathrm{V})$ = avian influenza (virus); dpi = days post infection; HP = highly pathogenic; IFN = interferon; LP = low pathogenic
}

$16 \mathrm{HA}[\mathrm{H} 1-\mathrm{H} 16]$ and 9 NA [N1-N9] subtypes have been isolated from wild aquatic birds (Webster et al., 1992; Olsen et al., 2006; Krauss and Webster, 2010; Marchenko et al., 2012). Influenza A virus infections in wild aquatic birds are predominantly maintained by asymptomatic condition (Taubenberger and Kash, 2010; França and Brown, 2014). Generally, ducks are considered a naturally resistant host for $\mathrm{H} 5 \mathrm{~N} 1$ influenza virus infection (Kida et al., 1980; Barber et al., 2010) and act as main reservoir for influenza A viruses (Hulse-Post et al., 2005; Songserm et al., 2006; Kim et al., 2009). Most H5N1 virus infections in ducks cause no or mild clinical disease and lesions (Alexander et al., 1986; Perkins and Swayne, 2002; Songserm et al., 2006). However, this situation has changed after evolution of Eurasian-African lineage of highly pathogenic avian influenza 
(AI) (HPAIV) H5N1 viruses from A/goose/Guandong/96(Gs/ GD) virus. This Eurasian-African lineage of H5N1 HPAIVs causes diseases in various wild aquatic and terrestrial bird species including ducks (Ellis et al., 2004; Chen et al., 2005; Brown et al., 2006, 2008; Pantin-Jackwood and Swayne, 2007; Pasick et al., 2007; Kim et al., 2012).

Various field outbreaks and experimental infection studies showed that ducks were susceptible to the infection by some Eurasian-African lineage $\mathrm{H} 5 \mathrm{~N} 1$ viruses, produce clinical signs ranging from mild clinical signs to death, with mortality rate approaching 31-80\% (Sturm-Ramirez et al., 2004; Zhou et al., 2006; Sun et al., 2011; Choi et al., 2013; Haider et al., 2015). The H5N1 virus-infected ducks showed the clinical signs, including torticollis, incoordination, tremors, seizures, whitish watery diarrhea, loss of appetite and sudden death (Ellis et al., 2004; Sturm-Ramirez et al., 2004; Kishida et al., 2005; Vascellari et al., 2007; Haider et al., 2015).

India has been experiencing outbreaks of HPAI H5N1 virus every year since it was first reported in Maharashtra State in February 2006 (Pattnaik et al., 2006; Tosh et al., 2007, 2011; Murugkar et al., 2008; Nagarajan et al., 2009). A/duck/Tripura/103597/2008 virus (hereafter mentioned as low pathogenic [LP] virus) was isolated from ducks and classified as $\mathrm{H} 5 \mathrm{~N} 1$ subtype and further phylogenetic analyses indicated that this virus belongs to clade 2.2, which includes viruses causing sporadic mortality in ducks. A/duck/India/02CA10/2011 virus (hereafter mentioned as highly pathogenic [HP] virus) was isolated from the natural outbreak of disease in parent duck flocks of Khaki Campbell breed in State Duck Breeding Farm, Agartala District of Tripura State. HP virus caused $61 \%$ mortality in ducks, was classified as $\mathrm{H} 5 \mathrm{~N} 1$ subtype and this virus belongs to clade 2.3.2.1 (Nagarajan et al., 2012).

The viral pathogenesis of AIV is a polygenic trait, which is associated with various factors including virus strain, species, age at infection, immune status and immune responses of the host. The extensive studies in human, animal models and various in vitro systems clearly indicate that host innate immune response plays a critical role in viral pathogenesis and outcome of an influenza virus infection (La Gruta et al., 2007; Maines et al., 2008). The complete understanding of host immune responses and role of host immune response in viral pathogenesis of ducks infected with different pathotypes of H5N1 influenza virus is still poorly understood. In order to determine the role the host immune response against two differentially pathogenic virus strains infection in ducks, we studied global lung tissue immune response of ducks infected with the high pathogenic virus (HP virus) and low pathogenic virus (LP virus). Our results suggest that the differential regulation of the host immune response might in part explain the difference observed in the viral pathogenesis of high and low pathogenic influenza strain infection in ducks.

\section{Materials and Methods}

Ethics statement. The animal experiments were carried out at the Biosafety level 3+ containment facility of ICAR-National Institute of High Security Animal Diseases, Bhopal, India, as per the guidelines of Institutional Animal Ethics Committee and Committee for the Purpose of Control and Supervision of Experiments on Animals (CPCSEA), Ministry of Environment and Forests, Govt. of India (Approval No. 68/IAEC/HSADL/12 dated 11.05.2012).

Virus. Two different H5N1 viruses isolated from ducks namely, A/duck/Tripura/103597/2008 belonging to clade 2.2 (LP virus) and $\mathrm{A} /$ duck/India/02CA10/2011 belonging to clade 2.3.2 (HP virus) were used in this study to assess the differential host immune response to different pathotypes. The stock viruses were propagated in the allantoic cavities of 12-day-old embryonated duck eggs. The Custom Duck 8x60k microarray (AMADID G4102A_059612) was designed using sequences available in the NCBI database for Anas platyrhynchos species on Agilent platform from Genotypic Technology Pvt. Ltd. A total of 23069 duck sequences were incorporated in the duck microarray chip.

Experimental infection of ducks. Six-week-old AIV-seronegative domestic ducks were divided into three groups, with each group containing 6 birds. Group 1 was intranasally inoculated with $10^{6} \mathrm{EID}_{50}$ of A/duck/Tripura/103597/2008 H5N1 (LP) virus isolate and the group 2 was inoculated with $10^{6} \mathrm{EID}_{50}$ of A/duck/India/02CA10/2011 H5N1 (HP) virus isolate. Group 3 was inoculated with PBS. Birds were observed daily for clinical signs. Three birds from each group were sacrificed at 5 days of post infection (dpi) and lung tissues collected in RNA later reagent $\left(\mathrm{Ambion}^{\mathrm{rx}}\right)$ ) and stored at $-80^{\circ} \mathrm{C}$. The remaining birds were observed for clinical signs up to $7 \mathrm{dpi}$. The virus infection in lungs was confirmed by tissue inoculation in embryonated chicken eggs and hemagglutination (HA) assay.

Total RNA isolation and microarray hybridization. Total RNA was isolated from the lung tissues of three birds from each infected group and two birds from non-infected group. Total RNA was isolated using TRIzol' Reagent (Invitrogen, USA) with the Qiagen's RNeasy mini kit (Qiagen, Germany). The integrity of RNA was analyzed on the Bioanalyzer (Agilent 2100). Total RNA was labeled using Agilent Quick Amp labeling kit by standard procedure. cRNA was purified using Qiagen RNeasy column. Concentration and amount of dye incorporated into labeled cRNA was determined using Nanodrop ND-1000 UV-VIS spectrophotometer. Samples that passed the QC for specific activity were taken for hybridization. 600 ng of labelled cRNA were hybridized on the specific arrays using the Gene Expression Hybridization kit in Sure Hybridization chambers at $65^{\circ} \mathrm{C}$ for $16 \mathrm{~h}$. Hybridized slides were washed using Agilent Gene Expression wash buffers. Washed microarray slides were scanned on a GS600D scanner (Agilent Technologies).

Microarray data analysis. Data extraction from images was done using Feature Extraction software version 10.7. Spot intensity was determined using a local background subtraction method. Percentile shift normalization method was used for normalization, where the locations of all the spot intensities in an array were adjusted. The 
Table 1. Oligonucleotide primers used for validation of microarray data

\begin{tabular}{lll}
\hline Gene name & Sequence $\mathbf{( 5}$ '-3') & Reference / Acc. No. \\
\hline Duck-MHCI-1-F & GAAGGAAGAGACTTCATTGCCTTGG & Maughan et al., 2013 \\
Duck-MHCI-1-R & CTCTCCTCTCCAGTACGTCCTTCC & Maughan et al., 2013 \\
Duck-MHCII-1-F & CCACCTTTACCAGCTTCGAG & \\
Duck-MHCII-1-R & CCGTTCTTCATCCAGGTGAT & XM_005031814.1 \\
Duck-SOCS3-F & AAGACGTTCAGCTCCAAGA & \\
Duck-SOCS3-R & AGTAGAAGCCGCTCTCCT & \\
\hline
\end{tabular}

normalized raw data were then subjected to a statistical analysis using GeneSpring GX 12.5 software (Agilent) to identify differentially expressed genes. The normalized raw data results obtained with LP or HP virus-infected lungs were compared to those obtained with control. Gene expression ratios compared with the reference control were calculated and transformed to $\log 2$ base. All the expression fold change values represented in the manuscript are log2-transformed values. The cut-off of $\mathrm{p}$-value $\leq 0.05$ and fold change value $+/-\geq 1$ ( $\log 2$-transformed value) was used to identify the significant differential expression. The microarray data have been deposited in NCBI Gene Expression Omnibus (Acc. No. GSE65230). The DE gene lists of these two viruses were compared in Venny tool to identify commonly up- or down-regulated or uniquely expressed to each virus. Functional classification of the DE genes was performed for gene ontology (GO) in Database for Annotation, Visualization and Integrated Discovery (DAVID) (Huang da et al., 2009) and pathway analysis in Kyoto Encyclopedia of Genes and Genomes (KEGG) (Kanehisa and Goto, 2000).

$R T-q P C R$ assays. The differential expression data was validated by RT-qPCR. Total RNA was isolated from triplicate of lung tissues using TRIzol ${ }^{\circledR}$ Reagent (Invitrogen, USA) with the Qiagen's RNeasy minikit (Qiagen, Germany). cDNA was synthesized from mRNA with random hexamer primer using Revert Aid First Strand cDNA Synthesis Kit \#K1621 (Thermo Scientific, USA). cDNA was subjected to real-time PCR using gene-specific primers by SYBR green chemistry. Primers used for RT qPCR were those previously reported (Maughan et al., 2013) or designed using Oligo Architect tool (Table 1). RT-qPCR was done on LightCycler ${ }^{\circ} 480$ System Real-Time PCR System (Roche Applied Science, USA) using USB ${ }^{\circledR}$ VeriQuest ${ }^{\oplus}$ SYBR $^{\oplus}$ Green qPCR Master Mix (2X) with Fluorescein ( $\mathrm{p} / \mathrm{n}$ 75665) (Affymetrix, Inc USA). The data obtained from the RT-qPCR was analyzed by Schmittegen and Livak (2008) method. The data was normalized using $\beta$-actin as the internal control gene. The $\Delta \Delta \mathrm{Ct}$ value was calculated as difference in normalized $\mathrm{Ct}$ value
( $\Delta \mathrm{Ct}$ ) from infected samples to the $\Delta \mathrm{Ct}$ from non-infected samples. The $\Delta \Delta \mathrm{Ct}$ value is transformed into $2^{-\Delta \Delta \mathrm{Ct}}$ value as the estimated gene expression fold change value.

\section{Results}

Host immune gene response to low pathogenic virus infection

The LP virus-infected ducks showed clinical signs including depression, loss of appetite and watery diarrhea. Hemagglutinin titer of the LP virus was found to be $2^{4}$. Global gene expression profiling of duck lungs infected with LP was done by microarray analysis of total RNA extracted from lung tissue collected at $5 \mathrm{dpi}$. A total of 1191 genes were significantly up-regulated and 1051 genes were significantly down-regulated ( $\mathrm{p}$-value $\leq 0.05$ and fold change value $+/-\geq 1$ ) (Table 2) with respect to control. We identified several immune genes up-regulated in lung tissues of duck in response to LP virus infection including 2',5'-oligo adenylate synthetase $(O A S)$, MX dynamin like GTPase $1(M X)$, suppressor of cytokine signaling 3 (SOCS3), interleukin 17 (IL17), interferon-induced protein with tetratricopeptide repeats 5 (IFIT5), interferon-induced transmembrane protein 5 (IFITM5), radical S-adenosyl methionine domain containing 2 (RSAD2), tripartite Motif Containing 23 (TRIM23), eukaryotic translation initiation factor 2 alpha kinase 2 (EIF2AK2), etc. Another set of the immune genes was also found to be down-regulated in LP virus infection, including toll like receptor 4 (TLR4), interferon gamma (IFN- $\gamma$ ), interferon alpha $(I F N-\alpha)$, and beta $(I F N-\beta)$, receptor subunit 1 (IFNLR1), signal transducer and activator of transcription 4 (STAT4), chemokine (C-C motif) ligand 5 (CCL5), chem-

Table 2. Summary of differentially expressed genes in response to infection with LP and HP viruses

\begin{tabular}{|c|c|c|c|c|}
\hline Infection condition & $\begin{array}{l}\text { Genes qualifying the } \\
\text { quality criteria }\end{array}$ & $\begin{array}{l}\text { Differentially expressed genes } \\
\qquad(+/-\geq 1 \text { folds, } p<0.05)\end{array}$ & $\begin{array}{l}\text { Up-regulated } \\
\text { genes }\end{array}$ & $\begin{array}{l}\text { Down-regulated } \\
\text { genes }\end{array}$ \\
\hline A/duck/Tripura/103597/2008 (LP virus) & 7350 & 2242 & 1191 & 1051 \\
\hline A/duck/India/02CA10/2011 (HP virus) & 6266 & 1566 & 770 & 796 \\
\hline
\end{tabular}


Table 3. Significantly enriched gene ontology terms in response to LP and HP virus infections

\begin{tabular}{|c|c|c|c|c|}
\hline \multirow{2}{*}{ GO term } & \multicolumn{2}{|c|}{ HP virus } & \multicolumn{2}{|c|}{ LP virus } \\
\hline & Gene count & p-value & Gene count & p-value \\
\hline Cellular homeostasis & 38 & $1.60 \mathrm{E}-03$ & 44 & $3.60 \mathrm{E}-02$ \\
\hline Cytokine receptor activity & 8 & $1.40 \mathrm{E}-02$ & - & NE \\
\hline Immune response & 45 & $3.00 \mathrm{E}-02$ & - & $\mathrm{NE}$ \\
\hline Induction of apoptosis & 23 & $5.50 \mathrm{E}-02$ & - & $\mathrm{NE}$ \\
\hline Inflammatory response & 27 & $7.00 \mathrm{E}-03$ & 33 & $3.00 \mathrm{E}-02$ \\
\hline Positive regulation of cellular biosynthetic process & 50 & $2.90 \mathrm{E}-03$ & 62 & $3.60 \mathrm{E}-02$ \\
\hline Positive regulation of gene expression & 44 & $2.80 \mathrm{E}-03$ & 0 & $0.00 \mathrm{E}+00$ \\
\hline Positive regulation of mononuclear cell proliferation & 9 & $4.80 \mathrm{E}-03$ & 8 & $9.30 \mathrm{E}-02$ \\
\hline Regulation of apoptosis & 69 & $2.50 \mathrm{E}-06$ & 76 & $5.50 \mathrm{E}-03$ \\
\hline Regulation of B cell activation & 9 & $2.60 \mathrm{E}-03$ & 8 & $6.20 \mathrm{E}-02$ \\
\hline Regulation of leukocyte activation & 13 & $9.90 \mathrm{E}-02$ & 8 & $9.30 \mathrm{E}-02$ \\
\hline Anti-apoptosis & 20 & $4.50 \mathrm{E}-03$ & 24 & $1.70 \mathrm{E}-02$ \\
\hline Positive regulation of lymphocyte proliferation & 9 & $4.30 \mathrm{E}-03$ & 8 & $8.70 \mathrm{E}-02$ \\
\hline Regulation of phosphorylation & 34 & $1.50 \mathrm{E}-02$ & 50 & $2.50 \mathrm{E}-03$ \\
\hline Response to cytokine stimulus & 10 & $1.30 \mathrm{E}-02$ & 11 & $4.70 \mathrm{E}-02$ \\
\hline Response to wounding & 40 & $4.70 \mathrm{E}-03$ & 55 & $3.10 \mathrm{E}-03$ \\
\hline T cell receptor signaling pathway & 4 & $9.40 \mathrm{E}-02$ & - & NE \\
\hline Transforming growth factor beta receptor signaling pathway & 9 & 7.30E-03 & - & NE \\
\hline Regulation of chemokine production & - & NE & 4 & $8.20 \mathrm{E}-02$ \\
\hline
\end{tabular}

$\mathrm{NE}=$ the GO term was not enriched to a specific infection condition.

Table 4. List of genes differentially expressed in response to LP and HP virus infections

\begin{tabular}{|c|c|c|}
\hline Gene name & Fold change in HP virus infection ( $\log 2$ value) & Fold change in LP virus infection ( $\log 2$ value) \\
\hline \multicolumn{3}{|c|}{ Up-regulated in HP virus infection and down-regulated in LP virus infection } \\
\hline ADAMTS1 & 1.002 & -1.054 \\
\hline FAM84B & 1.321 & -1.231 \\
\hline$I F N-\gamma$ & 1.270 & -1.275 \\
\hline KIAA0146 & 2.363 & -1.320 \\
\hline LOC101789899 & 1.005 & -2.568 \\
\hline LOC101791499 & 1.234 & -3.831 \\
\hline LOC101801272 & 1.883 & -1.702 \\
\hline LOC101801942 & 1.418 & -2.869 \\
\hline LOC101802795 & 1.961 & -1.230 \\
\hline LOC101804060 & 2.043 & -1.521 \\
\hline PRKDC & 2.320 & -5.923 \\
\hline RNASEL & 1.007 & -1.002 \\
\hline SHROOM1 & 1.013 & -1.198 \\
\hline SSTR1 & 2.614 & -1.048 \\
\hline TAP2 & 2.464 & -2.188 \\
\hline TRNAR-UCU & 3.303 & -2.166 \\
\hline \multicolumn{3}{|c|}{ Down-regulated in HP virus infection and up-regulated in LP virus infection } \\
\hline CCDC37 & -2.345 & 1.294 \\
\hline COLEC10 & -1.474 & 1.447 \\
\hline FAM53A & -1.732 & 1.063 \\
\hline GRIP1 & -1.863 & 1.129 \\
\hline ITGB6 & -2.364 & 1.800 \\
\hline$K L B$ & -2.119 & 1.595 \\
\hline LOC101790907 & -2.073 & 1.574 \\
\hline LOC101791514 & -2.147 & 2.310 \\
\hline
\end{tabular}


Table 4. (continue)

\begin{tabular}{lcc}
\hline Gene name & Fold change in HP virus infection $(\log 2$ value) & Fold change in LP virus infection (log2 value) \\
\hline Down-regulated in HP virus infection and up-regulated in LP virus & infection & 1.360 \\
\hline LOC101791947 & -6.017 & 1.273 \\
LOC101798529 & -1.596 & 1.284 \\
LOC101804087 & -1.195 & 1.905 \\
LRRC23 & -2.362 & 2.402 \\
MMACHC & -2.112 & 1.385 \\
NDUFAF4 & -1.935 & 2.163 \\
PP2D1 & -3.164 \\
PRDX1 & -2.464 & 1.893 \\
RAB36 & -3.105 & 1.268 \\
SLC12A3 & -1.263 & 1.040 \\
SNTN & -2.720 & 1.571 \\
UBR3 & -3.202 & 1.248 \\
WDR93 & -2.276 & 1.234 \\
IBX1 & -2.504 & 1.837 \\
\hline
\end{tabular}

okine (C-X-C motif) ligand 14 (CXCL14), IL16, TRIM63, etc. Gene ontology analysis of DE genes in DAVID revealed that the genes were involved in cellular homeostasis, B cell activation, leukocyte activation, negative regulation of apoptosis, positive regulation of molecular function, positive regulation of chemokine biosynthetic process, regulation of cytokine biosynthetic process, response to cytokine stimulus, etc. (Table 3). KEGG pathway analysis enriched the RIG-I-like receptor signaling pathway, chemokine signaling pathway, Jak-STAT signaling pathway, TNF signaling pathway, metabolic pathways, MAPK signaling pathway, cytokine-cytokine receptor interaction, TGF-beta signaling pathway, etc. (Fig. 1).

Host immune gene response to highly pathogenic virus infection

The HP virus-infected ducks gradually developed clinical signs such as depression, loss of appetite, watery eye discharge and torticollis observed on $7^{\text {th }}$ dpi. Hemagglutinin titer of the $\mathrm{HP}$ virus isolated from infected lung tissues was $2^{5}$. To identify genes contributing to the immune response to HP H5N1 influenza infection, we compared the infected tissue samples to non-infected samples. In HP virus infection, 770 genes were up-regulated and 796 genes were down-regulated in the lung tissues (Table 2). Among these up- and down-regulated genes, 880 genes were expressed only in HP virus infection. Particularly, HP virus induces expression of important immune genes such as IFITM2, STAT3, CCL4 and CXCR4 in lung tissue; these genes were reported to be associated with high pathogenic influenza virus infection in ducks. Higher induction of IFITM gene family, including IFITM1, 2 and 3 genes, during high pathogenic $\mathrm{H} 5 \mathrm{~N} 1$ virus infection in ducks determines the outcome of the disease (Smith et al., 2015).
Another study reported that differential expression pattern of STAT 3 gene may also determine differential outcome of highly pathogenic virus infection in ducks (Kuchipudi et al., 2014). Further KEGG pathways analysis revealed that HP virus activated various immune pathways, namely TLR, RIG-I and type I IFN pathways (Fig. 1) and results in a more pronounced induction of IFNs (IFN- $\gamma$ ), pro-inflammatory cytokines (IL17) and chemokines (CCL4 and CXCR4) expressed exclusively in HP virus infection conditions. The GO analysis of these differentially expressed genes in HP virus infection enriched similar biological processes as in response to LP virus infection (Table 3) (Fig. 1). However, there was quantitative difference in number of genes involved in particular biological process that were observed between the expression profiles of the two virus infections.

Comparative analysis of host gene expression responses between low pathogenic and highly pathogenic virus infection

To analyze the commonality of the host immune response to the two H5N1 viruses, LP and HP virus infections, we compared differentially expressed (up- or down-regulated) genes from each infection condition and identified the union of these gene lists. A total of 686 genes were found to be common between the two virus infections, indicating that ducks express the same 686 genes regardless of the H5N1 virus isolate (Fig. 2a). Of them, 348 genes were commonly up-regulated and 299 genes were commonly down-regulated in response to both virus infections (Fig. 2b). However, 39 genes were found to have differential expression pattern, of these 16 genes were up-regulated in HP virus infection but down-regulated in LP virus infection, and 23 genes were down-regulated in HP virus infection but up-regulated in LP virus infection (Fig. 2b) (Table 4). The functional annota- 


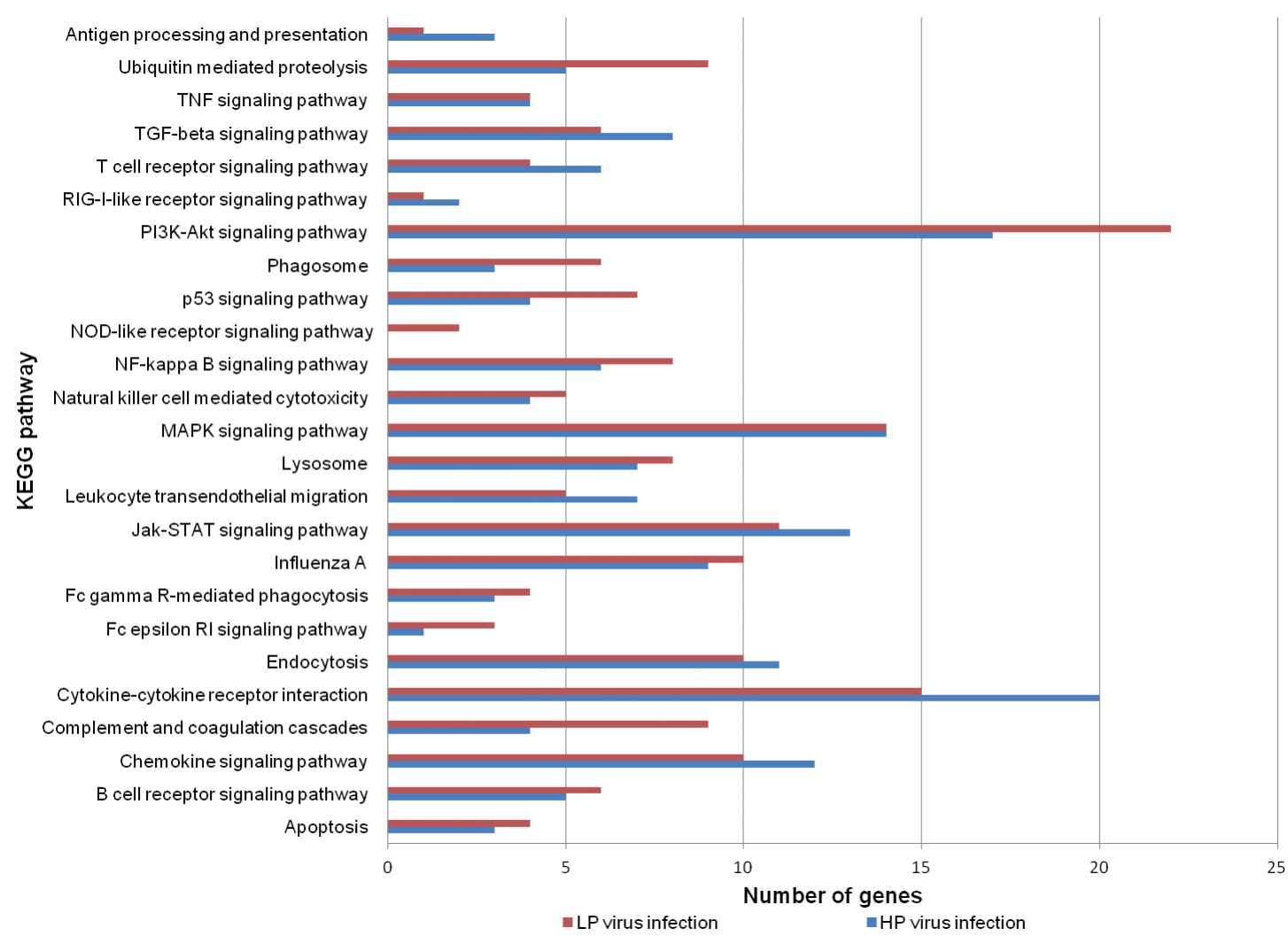

Fig. 1

KEGG pathways were differentially enriched in response to LP and HP virus infections

(a)

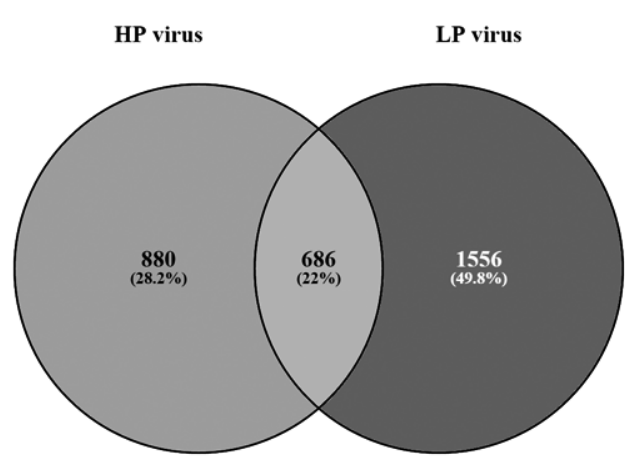

(b)

HP virus down $\quad$ LP virus up

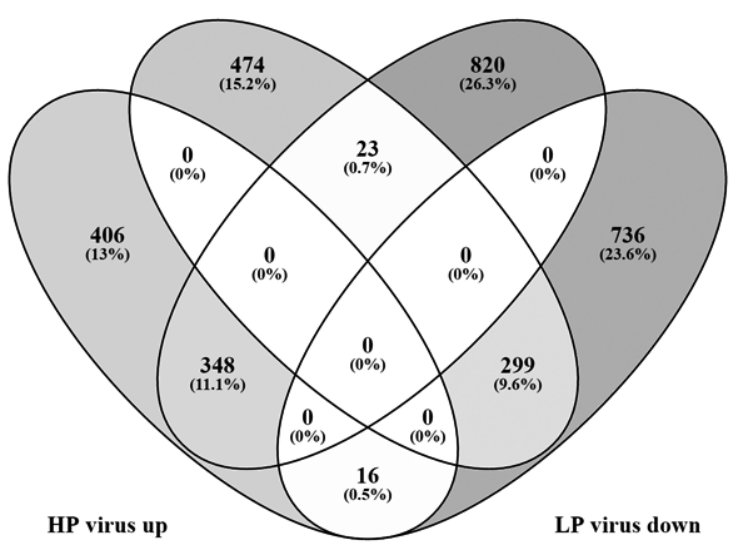

Fig. 2

Comparative analysis of gene expression changes between HP and LP virus infection conditions at 5 dpi

(a) Venn-diagram showing the comparison of genes list between HP and LP virus infection condition. (b)Venn-diagram showing the differential expression of commonly expressed genes between HP and LP virus infection conditions. 


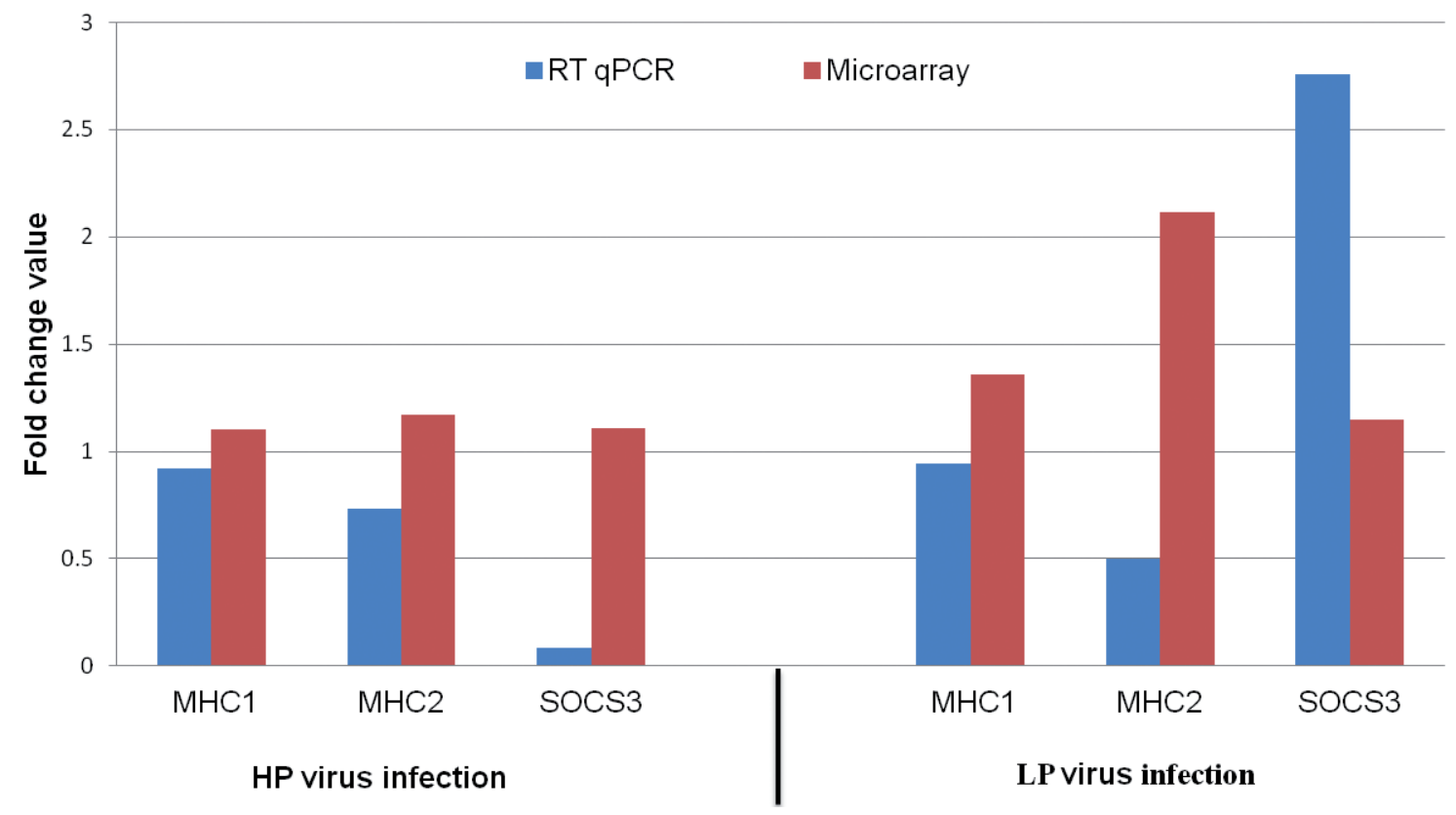

Fig. 3

Validation of microarray data by RT qPCR

tion of these 16 up-regulated genes related to the influenza A pathway, Cytokine-cytokine receptor interaction, JakSTAT signaling pathway, TGF-beta signaling pathway and the biological process of phosphorylation and regulation of cell proliferation. Further, the functional GO term annotation of the 23 down-regulated genes related to the host cell molecular function and cellular component. This functional annotation of differentially expressed genes results indicates that host immune related pathways and biological process were strongly activated during HP virus infection and normal host cell molecular function and hemostasis were suppressed or vise versa in case of LP virus infection condition. In further analysis of differences in host response to HP virus compared with LP virus infection, the immune genes such as MX, IFIT5, IFITM5, RSAD2, EIF2AK2 (PKR), $\beta$-defensins, $C X C L 14$, etc. were expressed in LP virus infection and these genes were not significantly expressed in HP virus-infected lung tissues. Similarly some of the immune genes (CCL4, CXCR4, IFITM2, transforming growth factor beta 1 (TGFB1) and TGFB3, IRF1, STAT3, etc.) were expressed only in HP virus infections but not in low pathogenic virus-infected lung tissues.

\section{Validation of microarray data by RT-qPCR}

A set of duck immune genes was assessed for the differential gene expression in lung tissues after HP or LP virus infection by RT-qPCR. Fig. 3 illustrates the changes in gene expression of the major histocompatibility complex (MHCs), and SOCS3. These genes were selected for their known role in the response to AIV infection. In comparison to microarray gene expression data, most of the fold change values were found to be compliant with microarray data though the magnitude sometimes differed.

\section{Discussion}

At field conditions A/duck/India/02CA10/2011 (HP virus) $\mathrm{H} 5 \mathrm{~N} 1$ virus (clade 2.3 .2 ) caused $61 \%$ mortality in ducks (Nagarajan et al., 2012), whereas sporadic mortality was observed in A/duck/Tripura/103597/2008 (LP virus) $\mathrm{H} 5 \mathrm{~N} 1$ virus (clade 2.2) infection. In experimental infection condition, HP virus-infected ducks developed neurological symptoms at $7 \mathrm{dpi}$ and no such symptoms or other clinical symptoms were observed at 7 dpi in LP virus-infected birds. Virus-induced host immune response plays an important role in the differences in viral pathogenesis observed between different pathotypes of influenza virus (Adams et al., 2009; Cui et al., 2014). In order to understand the differential host immune response, we studied the genome-wide host gene expression in duck lung tissues infected with high or low pathogenic strains of $\mathrm{H} 5 \mathrm{~N} 1$ viruses using custom-designed microarray chip. 
The recognition of pathogen-associated molecular patterns (PAMPs) by pattern recognition receptors (PRRs) triggers the activation of transcription factors and the expression of interferons, proinflammatory cytokines and chemokines (Kawai and Akira, 2010; Matsumiya and Stafforini, 2010; Iwasaki and Pillai, 2014). The microarray gene expression data indicate an up-regulation of $I F N-\gamma$ in HP virus infection compared to its down-regulation in LP virus infection. IFN- $\gamma$ up-regulation has been demonstrated in ducks in response to a LPAIV infection (Adams et al., 2009; Maughan et al., 2013). The H5N1 infection results in high transcriptional induction of IFNs, cytokines and chemokines in affected lung tissue and these play a major role in pathogenesis of $\mathrm{H} 5 \mathrm{~N} 1$ viruses (Baskin et al., 2009). By comparative analysis we found that the pattern of host immune gene response was quite different between HP and LP virus isolate. We observed the up-regulation of IFITM2, TGFB1 and TGFB3, STAT3, CCL4, CXCR4 genes following HP virus infection, but not LP virus infection. Further, OAS, IL17, and SOCS3 genes were expressed in both infection conditions, however, moderate differences were observed in expression levels of these genes in these two conditions. Previous studies have been done to compare the host immune responses of ducks infected with different pathogenic influenza strains. These studies suggest that the increased pathogenicity of more virulent influenza strain in ducks may be associated with rapid replication of the virus, accompanied by the robust host immune responses (retinoic acid-inducible gene 1 [RIG-I], IFN- $\alpha, I L-6, I L-8, I S G 12-2$, IFIT5, OASL and IFITM1), but minimal immune responses to a low virulent strain (Cagle et al., 2011; Pantin-Jackwood et al., 2012; Vanderven et al., 2012; Wei et al., 2013; Cui et al., 2014).

It is noteworthy that the expression of important antiviral immune genes, including IFIT5, IFITM5, $\beta$-defensins 6 , interferon-stimulated gene12-1 (ISG12-1), RSAD2, EIF2AK2 (PKR), CCL5, TRIM23, solute carrier family 16 member 3 (SLC16A3), was observed in LP virus infection, but not in $\mathrm{HP}$ virus infection. $\beta$-defensins are induced in response to influenza virus infection (Chong et al., 2008; Huang et al., 2013), inhibit AIV replication and increase the uptake of these viruses by neutrophils (Doss et al., 2009). ISG12 is involved in apoptosis of H5N1-influenza infected duck cells, which has been suggested as a mechanism of viral resistance (Kuchipudi et al., 2009). IFITM5 and IFIT genes have key roles in the antiviral response to AIV infection in mammals as well as ducks (Barber et al., 2010; Pichlmair et al., 2011; Huang et al., 2013). The differential expression of these important antiviral immune genes may modulate the viral pathogenesis in the LP virus infection making it apparently less pathogenic in ducks.

The genes involved in antigen processing and presentation, including MHC I alpha chain, MHC II beta chain, immunoglobulin lambda constant 1 and 2 (IGLC1 and 2) and beta 2 microglobulin, were up-regulated in lung tissues in response to both virus infections. The up-regulation of MHC I and MHC II genes was validated by RT qPCR assay. The MHC molecules are involved in the activation of specific acquired immunity to AIV infection and eliminate the pathogen; their up-regulation during AIV infection has been reported in ducks (Vanderven et al., 2012; Huang et al., 2013; Wei et al., 2013).

Differences in enrichment of different signaling pathways and GO terms were implicated into the difference between low pathogenic and high pathogenic influenza strain infection in ducks (Massin et al., 2013; Maughan et al., 2013). The cellular immune pathways such as chemokine signaling pathway, cytokine-cytokine receptor interaction, MAPK signaling pathway, NF-kappa B signaling pathway, TGF-beta signaling pathway, Toll-like receptor signaling pathway, RIG-I-like receptor signaling pathway, Jak-STAT signaling pathway, TNF signaling pathway, etc. are activated in response to infection with either virus in ducks. These pathways confirmed a similar innate immune response to both viruses; however, there were quantitative differences in number of genes involved in these pathways following infection with the two studied viruses. Further details of molecular mechanisms of activation of these pathways and interaction of these various pathways need to be studied in ducks. GO terms analysis of genes responsive to HP virus infection enriched the terms such as response to cytokine stimulus, induction of apoptosis, inflammatory response and response to wounding; these GO terms may suggest that HP virus induces hyper-immune responses in ducks. In contrast, in response to LP virus infection the terms related to regulation of apoptosis, homeostatic process, regulation of chemokine production and regulation of cytokine biosynthetic process are enriched, which may suggest that LP virus-induced successful moderate immune response allows the host to survive the LP infection.

Some of the well known AI responsive genes such as IFN- $\alpha, I F N-\beta$, RIG I, TLR3, TLR7, other interleukins, etc. were not significantly recovered in both samples at cut-off of $p$-value $\leq 0.05$ and fold change value $+/-\geq 1$. This may be due to the fact that the stringent $\mathrm{p}$-value cutoffs typically applied during microarray analysis can often obscure interesting trends in the expression data (Lee et al., 2009). Also, the duck genome is only preliminarily annotated at present and probably, since the array was designed on the basis of this draft genome, it resulted in high background levels owing to cross-hybridization, saturation and spot density. The status of the expression of these important genes may need to be studied with a more sensitive tool like RNA seq.

In conclusion, transcriptome analysis of duck lungs infected with the different H5N1 isolates (HP and LP) reveals differences in the magnitude of host immune responses. This can be speculated to be the cause of difference in outcome of the disease 
in ducks when infected with these isolates. This study provides a useful background information regarding relationship between $\mathrm{H} 5 \mathrm{~N} 1$ viral pathogenesis and host immune response in ducks. Further studies will be required to characterize the pathogenicity factors of influenza strain and the host immune response in order to understand the complete viral molecular pathogenesis and outcome of disease in ducks.

Acknowledgements. We thank the Directors of ICAR-Indian Veterinary Research Institute (IVRI), Izatnagar, India and ICARNational Institute of High Security Animal Diseases (NIHSAD), Bhopal, India for providing necessary facilities to carry out this work. This work was funded by the Department of Biotechnology, Government of India (Grant No. BT/IN/Indo-UK/FADH/48/ AM/2013) and ICAR-National Institute of High Security Animal Diseases (Institute-funded research project). Special thanks to Mohamed Aiyaz from Genotypic Technology Pvt. Ltd. for his technical support of microarray data submission.

\section{References}

Adams SC, Xing Z, Li J, Cardona CJ (2009): Immune-related gene expression in response to H11N9 low pathogenic avian influenza virus infection in chicken and Pekin duck peripheral blood mononuclear cells. Mol. Immunol. 46, 1744-1749. https://doi.org/10.1016/j. molimm.2009.01.025

Barber MR, Aldridge JR Jr, Webster RG, Magor KE (2010): Association of RIG-I with innate immunity of ducks to influenza. Proc. Natl. Acad. Sci. USA 107, 5913-5918. https://doi. org/10.1073/pnas.1001755107

Baskin CR, Bielefeldt-Ohmann H, Tumpey TM, Sabourin PJ, Long JP, García-Sastre A, Tolnay AE, Albrecht R, Pyles JA, Olson PH, Aicher LD, Rosenzweig ER, Murali-Krishna K, Clark EA, Kotur MS, Fornek JL, Proll S, Palermo RE, Sabourin CL, Katze MG (2009): Early and sustained innate immune response defines pathology and death in nonhuman primates infected by highly pathogenic influenza virus. Proc. Natl. Acad. Sci. USA 106, 3455-3460. https://doi.org/10.1073/pnas.0813234106

Brown JD, Stallknecht DE, Beck JR, Suarez DL, Swayne DE (2006): Susceptibility of North American ducks and gulls to H5N1 highly pathogenic avian influenza viruses. Emerg. Infect. Dis. 12,1663-1670. https://doi.org/10.3201/ eid1211.060652

Brown JD, Stallknecht DE, Swayne DE (2008): Experimental infection of swans and geese with highly pathogenic avian influenza virus (H5N1) of Asian lineage. Emerg. Infect. Dis. 14,136-142. https://doi.org/10.3201/eid1401.070740

Cagle C, To TL, Nguyen T, Wasilenko J, Adams SC, Cardona CJ, Spackman E, Suarez DL, Pantin-Jackwood MJ (2011): Pekin and Muscovy ducks respond differently to vaccination with a H5N1 highly pathogenic avian influenza (HPAI) commercial inactivated vaccine. Vaccine 29, 6549-6557. https://doi.org/10.1016/j.vaccine.2011.07.004
Choi J G, Kang H M, Jeon W J, Choi K S, Kim K I, Song B M, Lee H S, Kim J H, and Lee Y J (2013): Characterization of clade 2.3.2.1 H5N1 highly pathogenic avian influenza viruses isolated from wild birds (mandarin duck and Eurasian eagle owl) in 2010 in Korea. Viruses 5, 1153-1174. https:// doi.org/10.3390/v5041153

Chong KT, Thangavel RR, Tang X (2008): Enhanced expression of murine beta-defensins (MBD-1, -2,-3, and -4) in upper and lower airway mucosa of influenza virus infected mice. Virology 380, 136-143. https://doi.org/10.1016/j. virol.2008.07.024

Cui Z, Hu J, He L, Li Q, Gu M, Wang X, Hu S, Liu H, Liu W, Liu X, Liu X (2014): Differential immune response of mallard duck peripheral blood mononuclear cells to two highly pathogenic avian influenza $\mathrm{H} 5 \mathrm{~N} 1$ viruses with distinct pathogenicity in mallard ducks. Arch. Virol. 159, 339-343. https://doi.org/10.1007/s00705-013-1820-6

Doss M, White MR, Tecle T, Gantz D, Crouch EC, Jung G, Ruchala P, Waring AJ, Lehrer RI, Hartshorn KL (2009): Interactions of alpha-, beta-, and theta-defensins with influenza A virus and surfactant protein D. J. Immunol. 182, 7878-7887. https://doi.org/10.4049/jimmunol.0804049

Ellis TM, Bousfield RB, Bissett LA, Dyrting KC, Luk GS, Tsim ST, Sturm-Ramirez K, Webster RG, Guan Y, Malik Peiris JS (2004): Investigation of outbreaks of highly pathogenic $\mathrm{H} 5 \mathrm{~N} 1$ avian influenza in waterfowl and wild birds in Hong Kong in late 2002. Avian Pathol. 33, 492-505. https://doi.org/10.1080/03079450400003601

França MS, Brown JD (2014): Influenza pathobiology and pathogenesis in avian species. Curr. Top. Microbiol. Immunol. 385, 221-242. https://doi.org/10.1007/82 $2014 \quad 385$

Haider N, Sturm-Ramirez K, Khan SU, Rahman MZ, Sarkar S, Poh MK, Shivaprasad HL, Kalam MA, Paul SK, Karmakar PC, Balish A, Chakraborty A, Mamun AA, Mikolon AB, Davis CT, Rahman M, Donis RO, Heffelfinger JD, Luby SP, Zeidner N (2017): Unusually High Mortality in Waterfowl Caused by Highly Pathogenic Avian Influenza A(H5N1) in Bangladesh. Transbound Emerg. Dis. 64, 144-156. http://www.cdc.gov/flu/avianflu/influenza-a-virussubtypes.htm on 21.10.2015. https://doi.org/10.1111/ $\underline{\text { tbed. } 12354}$

Huang da W, Sherman BT, Lempicki RA (2009): Systematic and integrative analysis of large gene lists using DAVID bioinformatics resources. Nat. Protoc. 4, 44-57. https://doi. org/10.1038/nprot.2008.211

Huang Y, Li Y, Burt DW, Chen H, Zhang Y, Qian W, Kim H, Gan S, Zhao Y, Li J, Yi K, Feng H, Zhu P, Li B, Liu Q, Fairley S, Magor KE, Du Z, Hu X, Goodman L, Tafer H, Vignal A, Lee T, Kim KW, Sheng Z, An Y, Searle S, Herrero J, Groenen MA, Crooijmans RP, Faraut T, Cai Q, Webster RG, Aldridge JR, Warren WC, Bartschat S, Kehr S, Marz M, Stadler PF, Smith J, Kraus RH, Zhao Y, Ren, L, Fei J, Morisson M, Kaiser P, Griffin DK, Rao M, Pitel F, Wang J, Li N (2013): The duck genome and transcriptome provide insight into an avian influenza virus reservoir species. Nat. Genet. 45, 776-783. https://doi.org/10.1038/ng.2657

Hulse-Post DJ, Sturm-Ramirez KM, Humberd J, Seiler P, Govorkova EA, Krauss S, Scholtissek C, Puthavathana P, Buranathai 
C, Nguyen TD, Long HT, Naipospos TS, Chen H, Ellis TM, Guan Y, Peiris JS, Webster RG (2005): Role of domestic ducks in the propagation and biological evolution of highly pathogenic H5N1 influenza viruses in Asia. Proc. Natl. Acad. Sci. USA 102, 10682-10687. https:// doi.org/10.1073/pnas.0504662102

Iwasaki A, Pillai PS (2014): Innate immunity to influenza virus infection. Nat. Rev. Immunol. 14, 315-328. https://doi. org/10.1038/nri3665

Kanehisa M, Goto S (2000): KEGG: Kyoto Encyclopedia of Genes and Genomes. Nucleic Acids Res. 28, 27-30. https://doi. org/10.1093/nar/28.1.27

Kawai T, Akira S (2010): The role of pattern-recognition receptors in innate immunity: update on Toll-like receptors. Nat. Immunol. 11, 373-384. https://doi.org/10.1038/ni.1863

Kida H, Yanagawa R, Matsuoka Y (1980): Duck influenza lacking evidence of disease signs and immune response. Infect. Immun. 30, 547-553.

Kim HR, Lee YJ, Park CK, Oem JK, Lee OS, Kang HM, Choi JG, Bae YC (2012): Highly pathogenic avian influenza (H5N1) outbreaks in wild birds and poultry, South Korea. Emerg. Infect. Dis. 18, 480-483. https://doi. org/10.3201/1803.111490

Kim JK, Negovetich NJ, Forrest HL, Webster RG (2009): Ducks: the "Trojan horses" of H5N1 influenza. Influenza Other Respir. Viruses 3, 121-128. https://doi.org/10.1111/ j.1750-2659.2009.00084.X

Kishida N, Sakoda Y, Isoda N, Matsuda K, Eto M, Sunaga Y, Umemura T, Kida H (2005): Pathogenicity of H5 influenza viruses for ducks. Arch. Virol. 150, 1383-1392. https:// doi.org/10.1007/s00705-004-0473-X

Krauss S, Webster RG (2010): Avian influenza virus surveillance and wild birds: past and present. Avian Dis. 54, 394-398. https://doi.org/10.1637/8703-031609-Review.1

Kuchipudi SV, Nelli R, White GA, Bain M, Chang KC, Dunham $S$ (2009): Differences in influenza virus receptors in chickens and ducks: Implications for interspecies transmission. J. Mol. Genet. Med. 3, 143-151. https://doi. org/10.4172/1747-0862.1000026

Kuchipudi SV, Tellabati M, Sebastian S, Londt BZ, Jansen C, Vervelde L, Brookes SM, Brown IH, Dunham SP, Chang KC (2014): Highly pathogenic avian influenza virus infection in chickens but not ducks is associated with elevated host immune and pro-inflammatory responses. Vet. Res. 45,118. https://doi.org/10.1186/s13567-014-0118-3

Lee MS, Kim YJ (2007): Signaling pathways downstream of patternrecognition receptors and their cross talk. Annu. Rev. Biochem. 76, 447-480. https://doi.org/10.1146/annurev. biochem.76.060605.122847

Lee SMY, Gardy JL, Cheung CY, Cheung TKW, Hui KPY, Ip NY, Guan Y, Hancock RE, Peiris JS (2009): Systems-Level Comparison of Host-Responses Elicited by Avian H5N1 and Seasonal H1N1 Influenza Viruses in Primary Human Macrophages. PLoS ONE 4, e8072. https://doi. org/10.1371/journal.pone.0008072

Maines TR, Szretter KJ, Perrone L, Belser JA, Bright RA, Zeng H, Tumpey TM, Katz JM (2008): Pathogenesis of emerging avian influenza viruses in mammals and the host innate immune response. Immunol. Rev. 225, 68-84. https://doi. org/10.1111/j.1600-065X.2008.00690.X

Marchenko VY, Alekseev AY, Sharshov KA, Petrov VN, Silko NY, Susloparov IM, Tserennorov D, Otgonbaatar D, Savchenko IA, Shestopalov AM (2012): Ecology of influenza virus in wild bird populations in Central Asia. Avian Dis. 56, 234-237. https://doi.org/10.1637/9834061611-ResNote.1

Matsumiya T, Stafforini DM (2010): Function and regulation of retinoic acid inducible gene-I. Crit. Rev. Immunol. 30, 489-513. https://doi.org/10.1615/CritRevImmunol.v30. $\underline{\mathrm{i} 6.10}$

Maughan MN, Dougherty LS, Preskenis LA, Ladman BS, Gelb J Jr, Spackman EV, Keeler CL Jr (2013): Transcriptional analysis of the innate immune response of ducks to different species-of-origin low pathogenic $\mathrm{H} 7$ avian influenza viruses. Virol. J. 10, 94. https://doi.org/10.1186/1743$\underline{422 X-10-94}$

Murugkar HV, Nagarajan S, Tosh C, Bhatia S, Venkatesh G, Jain R, Kumar S, Khandia R, Pandey M, Behera P, Tripathy S, KulkarniDD, Dubey SC (2008): H5N1 virus outbreaks in poultry in India. Vet Rec. 162, 255. https://doi. org/10.1136/vr.162.8.255-a

Nagarajan S, Murugkar HV, Tosh C, Behera P, Jain R, Tripathi S, Khandia R, Gupta V, Kulkarni DD, Dubey SC (2009): Avian influenza virus (H5N1) in chickens in India. Vet Rec. 164, 128. https://doi.org/10.1136/vr.164.4.128

Nagarajan S, Tosh C, Smith DK, Peiris JSM, Murugkar HV, Sridevi R, Kumar M, Katare M, Jain R, Syed Z, Behera P, Cheung CL, Khandia R, Tripathi S, Guan Y, Dubey SC (2012): Avian Influenza (H5N1) Virus of Clade 2.3.2 in Domestic Poultry in India. PLoS ONE 7, e31844. https://doi. org/10.1371/journal.pone.0031844

Olsen B, Munster VJ, Wallensten A, Waldenström J, Osterhaus AD, Fouchier RA (2006): Global patterns of influenza a virus in wild birds. Science 312, 384-388. https://doi. org/10.1126/science. 1122438

Pantin-Jackwood MJ, Smith DM, Wasilenko JL, Cagle C, Shepherd E, Sarmento L, Kapczynski DR, Afonso CL (2012): Effect of age on the pathogenesis and innate immune responses in Pekin ducks infected with different H5N1 highly pathogenic avian influenza viruses. Virus Res. 167, 196-206. https://doi.org/10.1016/j.virusres.2012.04.015

Pantin-Jackwood MJ, Swayne DE (2007): Pathobiology of Asian highly pathogenic avian influenza $\mathrm{H} 5 \mathrm{~N} 1$ virus infections in ducks. Avian Dis. 51, 250-259. https://doi. org/10.1637/7710-090606R.1

Pasick J, Berhane Y Embury-Hyatt C, Copps J, Kehler H, Handel K, Babiuk S, Hooper-McGrevy K, Li Y, Mai Le Q, Lien Phuong S (2007): Susceptibility of Canada geese (Branta canadensis) to highly pathogenic avian influenza virus (H5N1). Emerg. Infect. Dis. 13, 1821-1827. https://doi. org/10.3201/eid1312.070502

Pattnaik B, Pateriya AK, Khandia R, Tosh C, Nagarajan S, Gounalan S, Murugkar HV, Shankar BP, Shrivastava N, Behera P, Bhagat S, Peiris JSM, Pradhan HK (2006): Phylogenetic analysis revealed genetic similarity of the $\mathrm{H} 5 \mathrm{~N} 1$ avian influenza viruses isolated from HPAI outbreaks in chickens 
in Maharashtra, India with those isolated from swan in Italy and Iran in 2006. Curr. Sci. 91, 77-81.

Pichlmair A, Lassnig C, Eberle CA, Górna MW, Baumann CL, Burkard TR, Bürckstümmer T, Stefanovic A, Krieger S, Bennett KL, Rülicke T, Weber F, Colinge J, Müller M, Superti-Furga G (2011): IFIT1 is an antiviral protein that recognizes 5 '-triphosphate RNA. Nat. Immunol. 12, 624-630. https://doi.org/10.1038/ni.2048

Schmittgen TD, Livak KJ (2008): Analyzing real-time PCR data by the comparative C(T) method. Nat. Protoc. 3, 1101-1108. https://doi.org/10.1038/nprot.2008.73

Smith J, Smith N, Yu L, Paton IR, Gutowska MW, Forrest HL, Danner AF, Seiler JP, Digard P, Webster RG, Burt DW (2015): A comparative analysis of host responses to avian influenza infection in ducks and chickens highlights a role for the interferon-induced transmembrane proteins in viral resistance. BMC Genomics 16, 574. https://doi. org/10.1186/s12864-015-1778-8

Songserm T, Jam-on R, Sae-Heng N, Meemak N, Hulse-Post DJ, Sturm-Ramirez KM, Webster RG (2006): Domestic ducks and H5N1 influenza epidemic, Thailand. Emerg. Infect. Dis. 12, 575-581. https://doi.org/10.3201/ eid1204.051614

Sturm-Ramirez K M, Ellis T, Bousfield B, Bissett L, Dyrting K, Rehg J E, Poon L, Guan Y, Peiris M, Webster R G (2004): Reemerging H5N1 influenza viruses in Hong Kong in 2002 are highly pathogenic to ducks. J. Virol 78, 4892-490. https://doi.org/10.1128/JVI.78.9.4892-4901.2004

Sun H, Jiao P, Jia B, Xu C, Wei L, Shan F, Luo K, Xin C, Zhang $\mathrm{K}$, Liao M (2011): Pathogenicity in quails and mice of $\mathrm{H} 5 \mathrm{~N} 1$ highly pathogenic avian influenza viruses isolated from ducks. Vet. Microbiol. 152, 258-265. https://doi. org/10.1016/j.vetmic.2011.05.009

Taubenberger JK, Kash JC (2010): Influenza virus evolution, host adaptation, and pandemic formation. Cell Host Microbe. 7, 440-51. https://doi.org/10.1016/j.chom.2010.05.009

Tosh C, Murugkar HV, Nagarajan S, Bhatia S, Pateriya AK, Behera P, Jain R, Kumar S, Khandia R, Vanamayya PR, Dubey
SC, Ahlawat SP (2007): Outbreak of avian influenza virus H5N1 in India. Vet. Rec. 161, 297. https://doi. org/10.1136/vr.161.8.279-a

Tosh C, Nagarajan S, Murugkar HV, Jain R, Behera P, Katare M, Kulkarni DD, Dubey SC (2011): Phylogenetic evidence of multiple introduction of $\mathrm{H} 5 \mathrm{~N} 1$ virus in Malda district of West Bengal, India in 2008. Vet. Microbiol. 148, 132-139. https://doi.org/10.1016/j.vetmic.2010.08.015

Vanderven HA, Petkau K, Ryan-Jean KE, Aldridge JR Jr, Webster RG, Magor KE (2012): Avian influenza rapidly induces antiviral genes in duck lung and intestine. Mol. Immunol. 51, 316-324. https://doi.org/10.1016/j. molimm.2012.03.034

Vascellari M, Granato A, Trevisan L, Basilicata L, Toffan A, Milani A, Mutinelli F (2007): Pathologic findings of highly pathogenic avian influenza virus A/Duck/Vietnam/12/05 (H5N1) in experimentally infected Pekin ducks, based on immunohistochemistry and in situ hybridization. Vet. Pathol. 44, 635-642. https://doi.org/10.1354/vp.44$\underline{5-635}$

Vijayakumar P, Mishra A, Ranaware PB, Kolte AP, Kulkarni DD, Burt DW, Raut AA (2015): Analysis of the crow lung transcriptome in response to infection with highly pathogenic $\mathrm{H} 5 \mathrm{~N} 1$ avian influenza virus. Gene 559, 77-85. https://doi. org/10.1016/j.gene.2015.01.016

Webster RG, Bean WJ, Gorman OT, Chambers TM, Kawaoka Y (1992): Evolution and ecology of influenza A viruses. Microbiol. Rev. 56, 152-179.

Wei L, Jiao P, Song Y, Cao L, Yuan R, Gong L, Cui J, Zhang S, Qi W, Yang S, Liao M (2013): Host immune responses of ducks infected with $\mathrm{H} 5 \mathrm{~N} 1$ highly pathogenic avian influenza viruses of different pathogenicities. Vet. Microbiol. 166, 386-393. https://doi.org/10.1016/j.vetmic.2013.06.019

Zhou JY, Shen HG, Chen HX, Tong GZ, Liao M, Yang HC, Liu JX (2006): Characterization of a highly pathogenic H5N1 influenza virus derived from bar-headed geese in China. J. Gen. Virol. 87, 1823-1833. https://doi.org/10.1099/ vir. $0.81800-0$ 